\title{
Comparative Study of Vaginal and Cesarean Section Delivery for Fetuses in Breech Presentation
}

\author{
${ }^{1}$ Vineeta Gupta, ${ }^{2}$ Amrita Makhija, ${ }^{3}$ Nidhi Kumari, ${ }^{4}$ Rashmi Kumari
}

\begin{abstract}
Objective: The present retrospective study was carried out to compare the maternal and fetal outcome in patients with breech presentation who delivered vaginally versus who delivered by cesarean section. The study also provided us with an opportunity to analyze the demographic and clinical profile between the two groups.

Materials and methods: The study was conducted in the Obstetrics Unit of Shri Guru Ram Rai Institute of Medical and Health Sciences and Shri Mahant Indiresh Hospital, Dehradun throughout 2 years. All patients admitted to the labor room with a singleton fetus in breech were included in the present study. All the patients were studied for their demographic profile, parity, gestational age, high-risk factors, mode of delivery, an indication of cesarean delivery and neonatal outcome. Maternal and neonatal outcome was compared between the patients who delivered vaginally versus who delivered by cesarean section using standard statistical methods.
\end{abstract}

Results: A total of 266 patients with breech presentation were included in the study, of which $95(35.71 \%)$ were delivered vaginally, $118(44.36 \%)$ underwent emergency cesarean section and $53(19.92 \%)$ had an elective cesarean section. Out of 266 , $145(54.51 \%)$ women were nulliparous and 121 (45.49\%) were multiparous. Both emergency and elective cesarean rates were more frequent in nulliparous women. The average period of gestation increased from $34.03 \pm 4.04$ weeks in the vaginal breech delivery group to $37.71 \pm 2.48$ weeks in the emergency cesarean group and $39.17 \pm 0.92$ weeks in the elective cesarean group. The most common indication for emergency cesarean delivery was refusal for the trial of vaginal delivery present in $52.54 \%$ and elective cesarean delivery it was primigravida with the breach in $47.17 \%$. The average birth weight of vaginally delivered babies was $1.819 \pm 0.70 \mathrm{~kg}$, for those delivered by emergency cesarean section it was $2.540 \pm 0.66 \mathrm{~kg}$ and for those delivered by elective cesarean section it was $2.942 \pm$ $0.50 \mathrm{~kg}$. A total of $218 \mathrm{Apgar}$ scores were compared excluding 37 patients who presented with IUD, 9 stillbirths and 2 patients with gross congenital malformations. It was noted that $65.38 \%$ of vaginally delivered babies had Apgar score of more than 7 at 5 minutes of birth as compared to $87.61 \%$ of babies delivered by emergency cesarean section and $100 \%$ of babies delivered

\footnotetext{
${ }^{1}$ Professor and Head, ${ }^{2}$ Senior Resident, ${ }^{3,4}$ Assistant Professor

${ }^{1-3}$ Department of Obstetrics and Gynaecology, SGRRIHMS and Shri Mahant Indiresh Hospital, Dehradun, Uttarakhand, India

${ }^{4}$ Department of Community Medicine, SGRRIHMS and Shri Mahant Indiresh Hospital, Dehradun, Uttarakhand, India

Corresponding Author: Vineeta Gupta, Profesor and Head, Department of Obstetrics and Gynaecology, SGRRIHMS and Shri Mahant Indiresh Hospital, Dehradun, Uttarakhand, India, Phone: 9758284395, e-mail: vineetahims@yahoo.co.in
}

by elective cesarean section. Overall $85.32 \%$ of babies had Apgar score more than 7 at 5 minutes of birth. There was no maternal mortality and no significant maternal morbidity in the different groups.

Conclusion: The present study concludes that planned vaginal delivery of both preterm and term breech in a carefully selected patient can be conducted after proper counseling of the patient with strict intrapartum monitoring and presence of obstetricians trained in the art of conducting breech deliveries.

Keyword: Breech presentation, Cesarean breech delivery, Vaginal breech delivery.

How to cite this article: Gupta V, Makhija A, Kumari N, Kumari R. Comparative Study of Vaginal and Cesarean Section Delivery for Fetuses in Breech Presentation. J South Asian Feder Obst Gynae 2018;10(Suppl 1):321-327.

Source of support: Nil

Conflict of interest: None

Ethical statement: The authors hereby declare that the article is original, neither the article nor a part of it is under consideration for publication anywhere else and has not been previously published anywhere. We have declared all vested interests. We have meticulously followed the instructions. The article if published shall be the property of the journal and we surrender all rights to the Editor. We declare that we have no conflict of interest.

Date of received: 15 October 2016

Date of acceptance: 12 June 2018

Date of publication: July 2019

\section{INTRODUCTION}

The incidence of breech presentation at term is about $3-4 \% .^{1-3}$ The incidence is higher in prematurity and associated fetal congenital anomalies. ${ }^{4}$ There is a lot of controversy in the mode of delivery of term as well as preterm breech. The term breech trial by Hannah et al. in the year 2000 changed the outlook towards breech deliveries which were historically being delivered vaginally. ${ }^{5}$ Cesarean section for delivering breech presentations was suggested as a way to reduce the associated perinatal problems. ${ }^{6}$ Planned cesarean deliveries became a routine for breech presentations because of improved neonatal outcomes. However, TBT was subjected to criticism. ${ }^{7}$ The art of delivering breech vaginally was lost. A two year follow up study was conducted which proved that perinatal outcomes, death or neurodevelopmental delay at 2 years were similar when delivering breech vaginally 
or by cesarean section. ${ }^{8}$ Thus, the interest in the conduct of vaginal breech delivery was reviewed. Another study proved that in units where planned vaginal delivery is a common practice, after careful patient selection delivering breech vaginally is safe if strict criteria are met. ${ }^{9}$ Such studies have a positive impact in developing countries where the perinatal mortality rate is high. Also due to the high fertility rate in such countries, reducing the cesarean rates decreases short term as well as long term maternal morbidity, besides decreasing hospital workload and financial burden.

The present retrospective study was carried out to compare the maternal and fetal outcome in patients with breech presentation who delivered vaginally versus who delivered by cesarean section. The study also provided us with an opportunity to analyze the demographic and clinical profile between the two groups.

\section{MATERIALS AND METHODS}

The study was conducted in the obstetrics unit of SGRR Institute of Medical and Health Sciences and Shri Mahant Indiresh Hospital, Dehradun throughout 2 years. All patients admitted to the labor room with a singleton fetus in breech were included in the present study. All the patients were studied for their demographic profile, parity, gestational age, high-risk factors, mode of delivery, an indication of cesarean delivery and neonatal outcome. Patients with twin gestations with breech presentation were excluded from the study.

On admission, the demographic profile of the patient was noted, and a detailed obstetrical, medical and surgical history was taken, followed by general, systemic and obstetrical examination. Routine investigations were done as per the hospital protocol. After proper counseling and consent, the patients were then subjected to vaginal delivery or cesarean section (emergency or elective). During a vaginal delivery, the fetal heart rate was auscultated every 30 minutes and progress of labor monitored every 2 hours. Emergency cesarean section was done if the arrest of progress or fetal distress was noted. Breech was delivered by assisted breech technique. After delivery of the baby, the Apgar score was noted at 1 minute and 5 minutes. The birth weight was also noted. Maternal and neonatal outcome was compared between the patients who delivered vaginally versus who delivered by cesarean section using standard statistical methods.

\section{RESULTS}

A total of 266 patients with breech presentation were included in the study. Out of these, 160 (60.15\%) was a term, and 106 (39.85\%) were preterm. Out of 266 patients, $95(35.71 \%)$ were delivered vaginally, 118 (44.36\%) under- went an emergency cesarean section and 53 (19.92\%) had an elective cesarean section.

Table 1 shows the demographic profile and gestational age at presentation. The average age was $27.06 \pm 4.54$ years for patients undergoing vaginal breech delivery, $25.62 \pm 3.92$ years in patients who had an emergency cesarean section and $27.38 \pm 4.10$ years in those undergoing an elective cesarean section. Of all the deliveries, 100 (37.59\%) were booked and 166 (62.40\%) were unbooked. Majority of the patients who had a vaginal delivery and emergency cesarean sections were unbooked (84.21\% and $60.17 \%$, respectively) in contrast to elective cesarean where the majority were booked $(71.70 \%)$.

Out of the 266 women included in the study, 145 were nulliparous. Of these, 44 (30.34\%) delivered vaginally. Out of the 121 multiparous women, 51 (42.15\%) delivered vaginally. Of the total 95 vaginal deliveries, 44 (46.32\%) occurred in nulliparous women and 51 (53.68\%) occurred in multiparous women. As seen in Graph 1, both emergency and elective cesarean rates were more frequent in nulliparous women.

Out of the total 171 cesarean sections, 101 (59.06\%) were done in nulliparous women and 70 (40.93\%) in multiparous women. There were 51 patients in the vaginal delivery group with no previous vaginal births (44 were primigravida, and 7 had a previous delivery by LSCS).

As seen in Graph 2, the average period of gestation was $34.03 \pm 4.04$ weeks in the vaginal breech delivery group with $22(23.16 \%)$ term deliveries and $73(76.84 \%)$ preterm deliveries. The average period of gestation in emergency cesarean section group was $37.71 \pm 2.48$ weeks with 86 (72.88\%) term deliveries and $32(27.12 \%)$ preterm deliveries and in the elective cesarean group the average period of gestation was $39.17 \pm 0.92$ weeks with 52 (98.11\%) term deliveries and $1(1.89 \%)$ preterm delivery due to PIH.

Since the hospital where the study was conducted is a tertiary care center, we had patients with various associated high-risk factors referred to us, as can be seen in Table 2. Medical disorders included seizure disorder (two patients), hypothyroidism (two patients), jaundice (five patients including three with hepatitis B virus infection), renal disease (one patient) and fever (two patients, one with diagnosed malaria and one with diagnosed enteric fever).

There was one patient with a large fibroid uterus who underwent emergency cesarean delivery, one patient with a bicornuate uterus who had a vaginal birth and one patient with longitudinal vaginal septum who delivered vaginally after excising the septum in the second stage of labor.

Out of the 118 patients undergoing emergency cesarean delivery, 24 patients had term PROM, and 11 patients had preterm PROM (including two patients with coexisting APH). Other patients undergoing vaginal 
Comparative Study of Vaginal and Cesarean Section Delivery for Fetuses in Breech Presentation

\begin{tabular}{|c|c|c|c|c|c|c|c|c|}
\hline & \multicolumn{2}{|c|}{$\begin{array}{l}\text { Vaginal breech } \\
\text { delivery }(n=95)\end{array}$} & \multicolumn{2}{|c|}{$\begin{array}{l}\text { Emergency cesarean } \\
\text { section }(n=118)\end{array}$} & \multicolumn{2}{|c|}{$\begin{array}{l}\text { Elective cesarean } \\
\text { section }(n=53)\end{array}$} & \multicolumn{2}{|c|}{ Total $(n=266)$} \\
\hline \multicolumn{9}{|l|}{ Age group (years) } \\
\hline & Number & $\%$ & Number & $\%$ & Number & $\%$ & Number & $\%$ \\
\hline$\leq 19$ & 0 & 0.00 & 0 & 0.00 & 0 & 0.00 & 0 & 0.00 \\
\hline $20-34$ & 85 & 89.47 & 113 & 95.76 & 50 & 94.34 & 248 & 93.23 \\
\hline$\geq 35$ & 10 & 10.53 & 5 & 4.24 & 3 & 5.66 & 18 & 6.77 \\
\hline \multicolumn{9}{|c|}{$\begin{array}{l}x^{2}=3.31, d f=1, p=0.068 ; p<0.05 \text { (significant) } \\
\text { Booking status }\end{array}$} \\
\hline Booked & 15 & 15.79 & 47 & 39.83 & 38 & 71.70 & 100 & 37.59 \\
\hline Unbooked & 80 & 84.21 & 71 & 60.17 & 15 & 28.30 & 166 & 62.41 \\
\hline \multicolumn{9}{|l|}{ Parity } \\
\hline Nullipara & 44 & 46.32 & 70 & 59.32 & 31 & 58.49 & 145 & 54.51 \\
\hline Multipara & 51 & 53.68 & 48 & 40.68 & 22 & 41.51 & 121 & 45.49 \\
\hline Para 1 & 20 & 21.05 & 38 & 32.20 & 18 & 33.96 & 76 & 28.57 \\
\hline Para 2 & 18 & 18.95 & 6 & 5.08 & 4 & 7.55 & 28 & 10.53 \\
\hline Para 3 & 8 & 8.42 & 3 & 2.54 & 0 & 0.00 & 11 & 4.14 \\
\hline Para 4 and above & 5 & 5.26 & 1 & 0.85 & 0 & 0.00 & 6 & 2.26 \\
\hline \multicolumn{9}{|c|}{$\begin{array}{l}x^{2}=4.003, d f=1, p=0.045 ; p<0.05 \text { (significant) } \\
\text { Gestational age (weeks) }\end{array}$} \\
\hline$<28$ & 8 & 8.42 & 0 & 0.00 & 0 & 0.00 & 8 & 3.01 \\
\hline $28-<32$ & 15 & 15.79 & 4 & 3.39 & 0 & 0.00 & 19 & 7.14 \\
\hline $32-<36$ & 38 & 40.00 & 21 & 17.80 & 0 & 0.00 & 59 & 22.18 \\
\hline $36-41$ & 32 & 33.68 & 90 & 76.27 & 52 & 98.11 & 174 & 65.41 \\
\hline$>41$ & 2 & 2.10 & 3 & 2.54 & 1 & 1.89 & 6 & 2.26 \\
\hline \multicolumn{9}{|c|}{$x^{2}=60.54, d f=3, p=0.000 ; p<0.001$ (highly significant) } \\
\hline
\end{tabular}

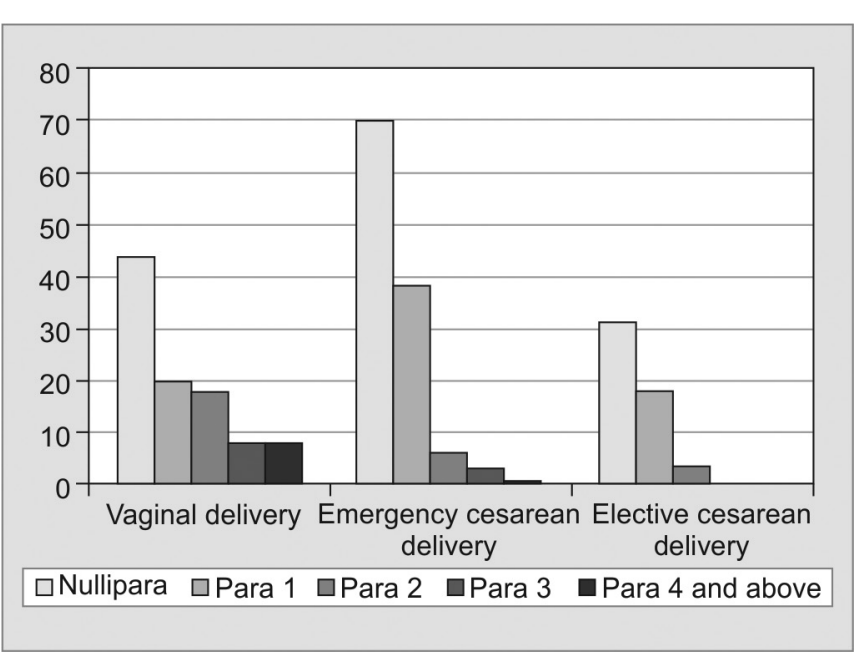

Graph 1: Mode of delivery related to the parity of the patients

delivery were taken for emergency cesarean section (for fetal distress, abruption and the arrest of descent). The indications of emergency and elective cesarean deliveries can be seen in Table 3 .

As seen in Graph 3, the average birth weight of all vaginally delivered babies was $1.819 \pm 0.70 \mathrm{~kg}$, for those delivered by emergency cesarean section was $2.540 \pm 0.66$ $\mathrm{kg}$ and for those delivered by elective cesarean section, it was $2.942 \pm 0.50 \mathrm{~kg}$. Table 4 shows the average birth weight distribution according to the gestational age.

Table 4 shows Apgar scores recorded for all live born babies at 1 minute and 5 minutes of birth. Babies

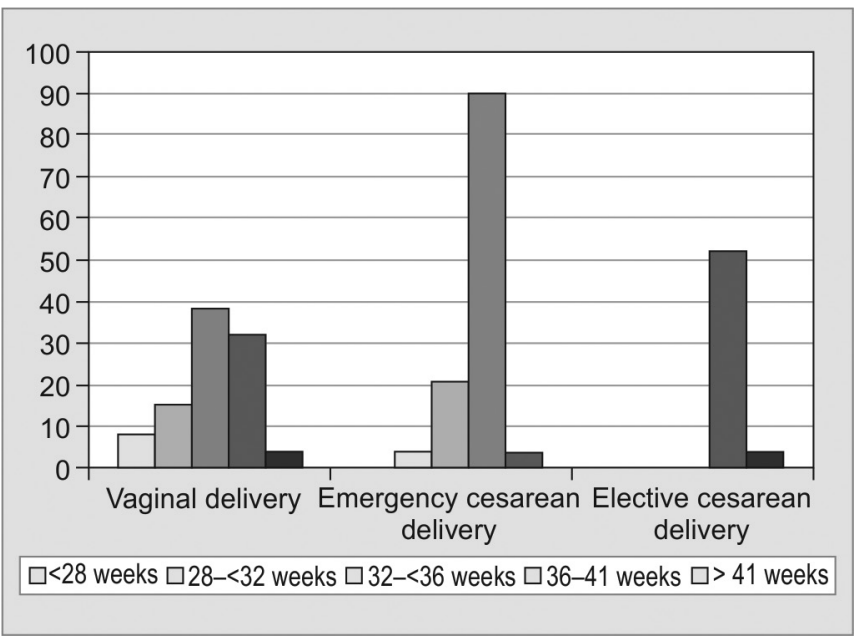

Graph 2: Mode of delivery related to gestational age

with major congenital malformations were excluded from the analysis of fetal outcome. Thus, Apgar scores of 52 babies born vaginally were compared to 113 born by emergency cesarean section and 53 born by elective cesarean section.

Apgar score of $<7$ at 1 minute of birth was seen in 14 babies and 12 babies in the vaginal delivery group and emergency cesarean group, respectively at 32-36 weeks gestation. Apgar score of $<7$ at 5 minutes of birth was seen in 9 babies delivered vaginally and 5 babies delivered by emergency cesarean. Thus, the Apgar score is comparable in both the groups. 
Table 2: High risk factors seen in patients with breech presentation with different modes of delivery

\begin{tabular}{|c|c|c|c|c|c|c|}
\hline \multirow[t]{2}{*}{$\begin{array}{l}\text { High risk } \\
\text { factor }\end{array}$} & \multicolumn{2}{|c|}{$\begin{array}{l}\text { Vaginal breech } \\
\text { delivery }(n=95)\end{array}$} & \multicolumn{2}{|c|}{$\begin{array}{l}\text { Emergency } \\
\text { cesarean } \\
\text { section } \\
(n=118)\end{array}$} & \multicolumn{2}{|c|}{$\begin{array}{l}\text { Elective } \\
\text { cesarean } \\
\text { section }(n=53)\end{array}$} \\
\hline & Number & $\%$ & Number & $\%$ & Number & $\%$ \\
\hline $\begin{array}{l}\text { Previous one } \\
\text { cesarean } \\
\text { section }\end{array}$ & 6 & 6.32 & 25 & 21.19 & 13 & 24.53 \\
\hline $\begin{array}{l}\text { Previous two } \\
\text { cesarean } \\
\text { section }\end{array}$ & 1 & 1.05 & 4 & 3.39 & 1 & 1.89 \\
\hline $\mathrm{PIH}$ total & 19 & 20.00 & 10 & 8.47 & 4 & 7.55 \\
\hline $\begin{array}{l}\text { Severe } \\
\text { preeclampsia }\end{array}$ & 5 & 5.26 & 0 & 0.00 & 0 & 0.00 \\
\hline Eclampsia & 4 & 4.21 & 5 & 4.24 & 0 & 0.00 \\
\hline $\begin{array}{l}\text { APH } \\
\text { (including } \\
\text { placenta } \\
\text { previa) }\end{array}$ & 0 & 0.00 & 9 & 7.63 & 7 & 13.21 \\
\hline $\begin{array}{l}\text { Placenta } \\
\text { previa }\end{array}$ & 1 & 1.05 & 4 & 3.39 & 2 & 3.77 \\
\hline GDM & 3 & 3.16 & 2 & 1.70 & 2 & 3.77 \\
\hline PROM & 15 & 15.79 & 35 & 29.66 & 1 & 1.89 \\
\hline $\begin{array}{l}\text { Rh negative } \\
\text { pregnancy }\end{array}$ & 5 & 5.26 & 5 & 4.24 & 2 & 3.77 \\
\hline $\begin{array}{l}\text { IUGR/Oligohy- } \\
\text { dramnios }\end{array}$ & 7 & 7.37 & 14 & 11.86 & 2 & 3.77 \\
\hline $\mathrm{IHCP}$ & 0 & 0.00 & 1 & 0.85 & 1 & 1.89 \\
\hline $\begin{array}{l}\text { Severe } \\
\text { anemia }\end{array}$ & 12 & 12.63 & 4 & 3.39 & 0 & 0.00 \\
\hline $\begin{array}{l}\text { Medical } \\
\text { disorders }\end{array}$ & 6 & 6.32 & 4 & 3.39 & 2 & 3.77 \\
\hline
\end{tabular}

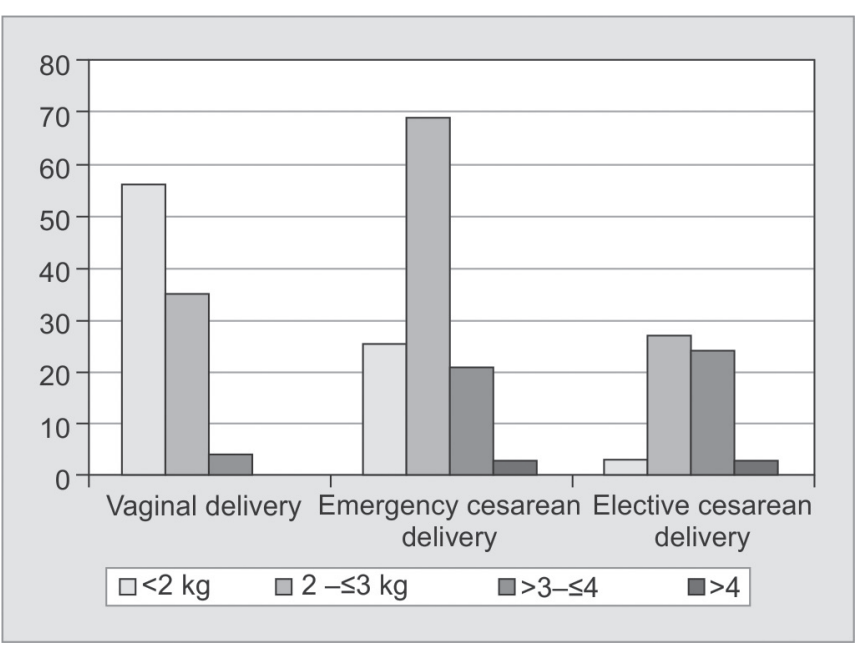

Graph 3: Mode of delivery related to birth weight

In 36 to 41 weeks group, Apgar score $<7$ at 1 minute was seen in 12 babies delivered vaginally, 12 babies delivered by emergency cesarean section and four babies delivered by elective cesarean. Apgar score of $<7$ at 5 minutes of birth was seen in three babies delivered vaginally, eight babies delivered by emergency cesarean but none delivered by elective cesarean section.
Table 3: Indication of emergency and elective cesarean sections

\begin{tabular}{|c|c|c|c|c|}
\hline \multirow{2}{*}{$\begin{array}{l}\text { Indication of } \\
\text { emergency LSCS } \\
(n=118)\end{array}$} & \multicolumn{2}{|c|}{ Term $(n=86)$} & \multicolumn{2}{|c|}{ Preterm $(n=32)$} \\
\hline & Number & $\%$ & Number & $\%$ \\
\hline \multicolumn{5}{|c|}{ Refusal for vaginal birth } \\
\hline PROM & 20 & 2.32 & 7 & 21.88 \\
\hline Labor pains & 29 & 33.72 & 6 & 18.75 \\
\hline \multicolumn{5}{|l|}{ Previous one LSCS } \\
\hline PROM & 4 & 4.65 & 1 & 3.12 \\
\hline Labor pains & 11 & 12.80 & 2 & 6.25 \\
\hline \multicolumn{5}{|l|}{ Previous two LSCS } \\
\hline PROM & 0 & 0.00 & 1 & 3.12 \\
\hline Labor pains & 2 & 2.32 & 1 & 3.12 \\
\hline Oligohydramnios & 6 & 6.98 & 3 & 9.38 \\
\hline Fetal distress & 5 & 5.81 & 1 & 3.12 \\
\hline Footling breech & 2 & 2.32 & 0 & 0.00 \\
\hline Abruption & 0 & 0.00 & 4 & 12.50 \\
\hline Placenta previa & 2 & 2.32 & 2 & 6.25 \\
\hline Arrest of descent & 1 & 1.17 & 0 & 0.00 \\
\hline Eclampsia & 0 & 0.00 & 4 & 12.50 \\
\hline $\mathrm{BOH}$ & 2 & 2.32 & 0 & 0.00 \\
\hline Macrosomia & 1 & 1.17 & 0 & 0.00 \\
\hline Failed ECV & 1 & 1.17 & 0 & 0.00 \\
\hline \multirow{2}{*}{$\begin{array}{l}\text { Indication of } \\
\text { elective LSCS } \\
(n=53)\end{array}$} & \multicolumn{2}{|c|}{ Term $(n=52)$} & \multicolumn{2}{|c|}{ Preterm $(n=1)$} \\
\hline & Number & $\%$ & Number & $\%$ \\
\hline Nulliparous breech & 25 & 48.08 & 0 & 0.00 \\
\hline $\begin{array}{l}\text { Previous cesarean } \\
\text { birth (total) }\end{array}$ & 14 & 26.92 & 0 & 0.00 \\
\hline Previous one LSCS & 11 & 21.15 & 0 & 0.00 \\
\hline $\begin{array}{l}\text { Placenta previa } \\
\text { with prev } 1 \text { LSCS }\end{array}$ & 1 & 1.92 & 0 & 0.00 \\
\hline $\begin{array}{l}\text { PIH with prev } 1 \\
\text { LSCS }\end{array}$ & 0 & 0.00 & 1 & 100 \\
\hline Previous two LSCS & 1 & 1.92 & 0 & 0.00 \\
\hline Good sized baby & 3 & 5.77 & 0 & 0.00 \\
\hline $\begin{array}{l}\text { Oligohydramnios/ } \\
\text { IUGR }\end{array}$ & 1 & 1.92 & 0 & 0.00 \\
\hline $\mathrm{BOH}$ & 1 & 1.92 & 0 & 0.00 \\
\hline $\begin{array}{l}\text { BOH with IUGR and } \\
\text { oligohydramnios }\end{array}$ & 1 & 1.92 & 0 & 0.00 \\
\hline GDM & 2 & 3.85 & 0 & 0.00 \\
\hline $\begin{array}{l}\text { Refusal for vaginal } \\
\text { delivery }\end{array}$ & 6 & 11.54 & 0 & 0.00 \\
\hline
\end{tabular}

Table 4 and Graph 4 show the distribution of Apgar scores at 5 minutes of birth according to the mode of delivery. A total of 218 Apgar scores were compared excluding 37 patients who presented with IUD, nine stillbirths and two patients with gross congenital malformations. Thus, $65.38 \%$ of vaginally delivered babies had Apgar score more than 7 at 5 minutes of birth as compared to $87.61 \%$ of babies delivered by emergency cesarean section and $100 \%$ of babies delivered by elective cesarean section. Overall $85.32 \%$ of babies had Apgar score more than 7 at 5 minutes of birth. 
Comparative Study of Vaginal and Cesarean Section Delivery for Fetuses in Breech Presentation

\begin{tabular}{|c|c|c|c|c|c|c|c|c|}
\hline \multicolumn{9}{|c|}{ Table 4: Neonatal Outcome } \\
\hline & \multicolumn{8}{|c|}{ Average birth weight $(\mathrm{kg})$} \\
\hline $\begin{array}{l}\text { Gestational age } \\
\text { (weeks) }\end{array}$ & \multicolumn{2}{|c|}{$\begin{array}{l}\text { Vaginal breech delivery } \\
(n=95)\end{array}$} & \multicolumn{2}{|c|}{$\begin{array}{l}\text { Emergency cesarean } \\
\text { section }(n=118)\end{array}$} & \multicolumn{2}{|c|}{$\begin{array}{l}\text { Elective cesarean section } \\
(n=53)\end{array}$} & \multicolumn{2}{|l|}{ Total $(n=266)$} \\
\hline$<32$ & \multicolumn{2}{|c|}{$1.118(n=23)$} & \multicolumn{2}{|l|}{$1.312(n=4)$} & \multicolumn{2}{|c|}{$(n=0)$} & & \\
\hline $32-<36$ & \multicolumn{2}{|l|}{$1.611(n=38)$} & \multicolumn{2}{|l|}{$2.012(n=21)$} & \multicolumn{2}{|l|}{$(n=0)$} & & \\
\hline $36-41$ & \multicolumn{2}{|l|}{$2.482(n=32)$} & \multicolumn{2}{|l|}{$2.701(n=90)$} & \multicolumn{2}{|c|}{$2.943(n=52)$} & & \\
\hline$>41$ & \multicolumn{2}{|l|}{$3.25(n=2)$} & \multicolumn{2}{|l|}{$3.077(n=3)$} & \multicolumn{2}{|c|}{$2.905(n=1)$} & & \\
\hline \multicolumn{9}{|c|}{ Mode of delivery related to birth weight } \\
\hline Birth weight (kg) & \multicolumn{2}{|c|}{ Vaginal delivery $(n=95)$} & \multicolumn{2}{|c|}{$\begin{array}{l}\text { Emergency cesarean } \\
\text { section }(n=118)\end{array}$} & \multicolumn{2}{|c|}{$\begin{array}{l}\text { Elective cesarean section } \\
(n=53)\end{array}$} & \multicolumn{2}{|l|}{$\begin{array}{l}\text { Total } \\
(n=266)\end{array}$} \\
\hline & Number & $\%$ & Number & $\%$ & Number & $\%$ & Number & $\%$ \\
\hline$\leq 2$ & 56 & 58.95 & 25 & 21.19 & 1 & 1.89 & 82 & 30.83 \\
\hline$>2-\leq 3$ & 35 & 36.84 & 69 & 58.47 & 27 & 50.94 & 131 & 49.25 \\
\hline$>3-\leq 4$ & 4 & 4.21 & 21 & 27.80 & 24 & 45.28 & 49 & 18.42 \\
\hline$>4$ & 0 & 0.00 & 3 & 2.54 & 1 & 1.89 & 4 & 1.50 \\
\hline \multicolumn{9}{|c|}{$x^{2}=58.303, \mathrm{df}=2, p=0.000 ; p<0.001$ (highly significant) } \\
\hline \multicolumn{9}{|c|}{ Apgar scores according to gestational age } \\
\hline & $\begin{array}{l}\text { Vaginal breec } \\
(n=52)\end{array}$ & h delivery & $\begin{array}{l}\text { Emergency c } \\
\text { section }(n=1\end{array}$ & $\begin{array}{l}\text { esarean } \\
\text { 13) }\end{array}$ & $\begin{array}{l}\text { Elective ces } \\
(n=53)\end{array}$ & arean section & Total $(n=218$ & \\
\hline $\begin{array}{l}\text { Gestational age } \\
\text { (weeks) }\end{array}$ & $\begin{array}{l}1 \text { minute } \\
\text { Apgar score } \\
<7\end{array}$ & $\begin{array}{l}5 \text { minute } \\
\text { Apgar } \\
\text { score }<7\end{array}$ & $\begin{array}{l}1 \text { minute } \\
\text { Apgar score } \\
<7\end{array}$ & $\begin{array}{l}5 \text { minute } \\
\text { Apgar } \\
\text { score }<7\end{array}$ & $\begin{array}{l}1 \text { minute } \\
\text { Apgar } \\
\text { score }<7\end{array}$ & $\begin{array}{l}5 \text { minute } \\
\text { Apgar score } \\
<7\end{array}$ & $\begin{array}{l}1 \text { minute } \\
\text { Apgar score } \\
<7\end{array}$ & $\begin{array}{l}5 \text { minute } \\
\text { Apgar } \\
\text { score }<7\end{array}$ \\
\hline$<32$ & $8(n=9)$ & $6(n=9)$ & $3(n=4)$ & $1(n=4)$ & NA & NA & $11(n=13)$ & $7(n=13)$ \\
\hline $32-<36$ & $14(n=19)$ & $9(n=19)$ & $12(n=18)$ & $5(n=18)$ & NA & NA & $26(n=37)$ & $14(n=37)$ \\
\hline $36-41$ & $12(n=22)$ & $3(n=22)$ & $12(n=89)$ & $8(n=89)$ & $4(n=52)$ & $0(n=52)$ & $28(n=163)$ & $11(n=163)$ \\
\hline$>41$ & $0(n=2)$ & $0(n=2)$ & $1(n=2)$ & $0(n=2)$ & $0(n=1)$ & $0(n=1)$ & $1(n=5)$ & $0(n=5)$ \\
\hline & & & ribution of Apg & ar score at 5 & minutes of bir & & & \\
\hline $\begin{array}{l}\text { Apgar score at } 5 \\
\text { min of birth }\end{array}$ & $\begin{array}{l}\text { Vaginal delive } \\
(n=52)\end{array}$ & & $\begin{array}{l}\text { Emergency c } \\
\text { section } \\
(n=113)\end{array}$ & esarean & $\begin{array}{l}\text { Elective ce } \\
\text { section } \\
(n=53)\end{array}$ & sarean & $\begin{array}{l}\text { Total } \\
(n=218)\end{array}$ & \\
\hline$\geq 7$ & $34(65.38 \%)$ & & $99(87.61 \%)$ & & $53(100 \%)$ & & $186(85.32 \%)$ & \\
\hline $4-<7$ & $14(26.92 \%)$ & & $11(9.73 \%)$ & & $0(0.00 \%)$ & & $25(11.47 \%)$ & \\
\hline$<4$ & $4(7.69 \%)$ & & $3(2.65 \%)$ & & $0(0.00 \%)$ & & $7(3.21 \%)$ & \\
\hline & & & $=21.676, \mathrm{df}=$ & $2, p=0.000$ & $p<0.001$ (hic & hly significant) & & \\
\hline
\end{tabular}

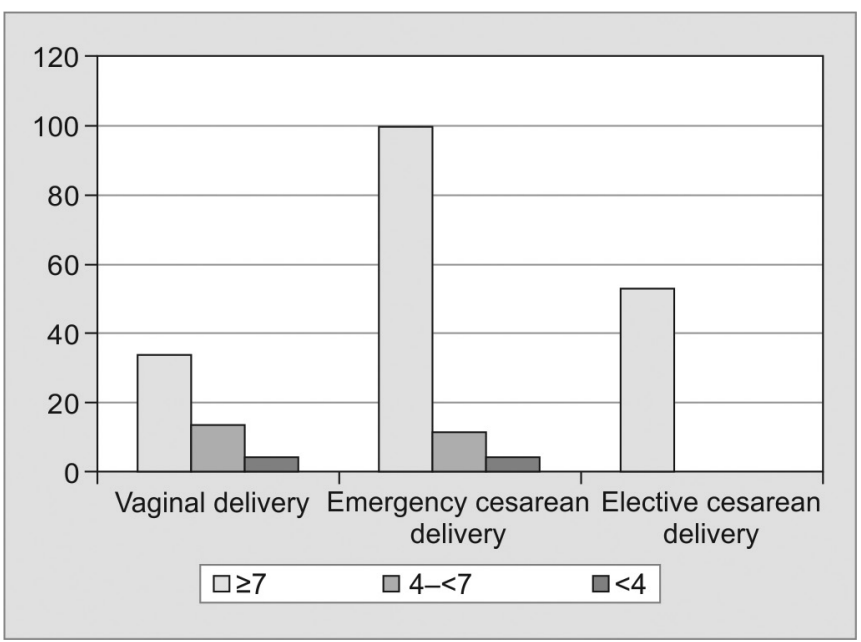

Graph 4: Mode of delivery and five minute Apgar score

Thirty-seven patients presented with IUD. Of these 32 were delivered vaginally and five were delivered by emergency cesarean section (two for placenta previa, one for previous two cesarean births, one for previous one cesarean birth and one for macrosomia). Also, there were nine stillbirths in the vaginal delivery group of which fourbabies had gross congenital anomalies, four were preterm, and one patient was referred with trapped aftercoming head and was delivered vaginally. There were no fatal injuries in either group.

There were nine patients with major congenital malformations in the fetus. Of these seven were delivered vaginally (three with hydrocephalous, one with encephalocele, one with anencephaly, one with the Dandy-Walker syndrome and one with anorectal malformation along with congenital diaphragmatic hernia). Two patients with congenital malformation in the fetus were delivered by cesarean section (one had hydrocephalous and one had hydronephrosis). Besides, there were two syndromic babies delivered by cesarean section who were diagnosed after birth (one with Charge syndrome and one with Edward syndrome).

There was no maternal mortality and no significant maternal morbidity was noted in any of the groups.

\section{DISCUSSION}

Majority of the patients were unbooked $(62.40 \%)$ and $93.23 \%$ patients were in the $20-34$ years age group. There 
were no teenage deliveries. Majority of the patients had term gestations $(60.15 \%)$ and most were nulliparous (54.51\%).

Of all the patients, $35.71 \%$ had a vaginal delivery. Majority of the vaginal deliveries were preterm (76.84\%). There were 8 vaginal deliveries where the period of gestation was less than 28 weeks. The average period of gestation in this group was $34.03 \pm 4.04$ weeks. This is in contrast to the findings of Singh et al. where maximum vaginal deliveries were a term. ${ }^{10}$ Only $19.92 \%$ patients had planned elective cesarean section, similar to $20.4 \%$ seen in the study by Singh et al. ${ }^{10}$ Emergency cesarean section was done in $44.36 \%$ patients. Most of these presented in the emergency with labor pains or PROM and opted for cesarean delivery. Twenty-nine patients had previous cesarean deliveries for which emergency cesarean delivery was done. However, vaginal birth was successfully conducted in six patients with previous one cesarean delivery and one patient with previous two cesarean deliveries.

In the present study, $30.34 \%$ of nulliparous women had a vaginal delivery as opposed to $42.15 \%$ of multiparous women. Both emergency and elective cesarean rates were more frequent in nulliparous women and the difference was statistically significant $\left(\chi^{2}=4.003, \mathrm{df}=1, p=\right.$ $0.045)$. Of all the cesarean sections, $59.06 \%$ were done in nulliparous women and $40.93 \%$ in multiparous women. Of all the breech vaginal deliveries, $46.32 \%$ occurred in nulliparous women, and $53.68 \%$ occurred in multiparous women. Nahid found increased rates of elective cesarean section in primipara; however, rates of emergency cesarean section were comparable between primipara and multipara in their study. ${ }^{11}$ Nulliparous breech delivery was also evaluated in a Cameroonian study where $66.7 \%$ had a vaginal delivery. ${ }^{12}$

The most common indication for emergency cesarean delivery was refusal for the trial of vaginal delivery present in $52.54 \%$ followed by previous cesarean delivery seen in $18.64 \%$ patients. In $7.63 \%$ emergency cesarean was done due to oligohydramnios and $5.08 \%$ had fetal distress. This is in contrast to the findings of the Term Breech Trial, where the failure of progress (50\%) and fetal distress (29\%) were the most common reasons for emergency cesarean section. ${ }^{5}$ The findings of Singh et al. are also dissimilar as they report previous cesarean scar and fetal distress as the most common indication. ${ }^{10}$

The most common indication for elective cesarean delivery was Primi breech in $47.17 \%$ followed by previous cesarean birth in $26.41 \%$, contrary to the findings of Nahid et al., were previous cesarean birth was the most common indication seen in $34 \%$ patients followed by primi breech in $22.34 \%{ }^{11}$ The findings of Singh et al. are also dissimi- lar as they report previous cesarean scar and feto pelvic disproportion as the most common indication. ${ }^{10}$

Out of the total of 63 patients with live fetus undergoing vaginal delivery, there were $9(14.28 \%)$ stillbirths which are higher than observed in many studies. 5,13 However, an Indian study reports neonatal mortality of $15.1 \%$ which seems comparable. ${ }^{10}$ Of all the stillborn fetuses four had gross congenital anomalies, four were pre-term, and one patient was referred with trapped aftercoming head and was delivered vaginally. There were no stillbirths in the emergency or elective cesarean group.

Out of the 37 patients who presented with IUD, 32 were delivered vaginally and five were delivered by emergency cesarean section (two for placenta previa, 1 for previous two cesarean births, one for previous one cesarean birth and one for macrosomia.).

Cesarean section rates increased with increasing birth weights and the difference was statistically highly significant $\left(\chi^{2}=58.303, \mathrm{df}=2, p=0.000\right)$. The frequency of cesarean sections in cases having birth weight $\leq 3 \mathrm{~kg}$ was $57.28 \%(122 / 213)$ as opposed to $92.45 \%(49 / 53)$ in cases with birth weight more than $3 \mathrm{~kg}$. This rise in the rates of cesarean sections with increasing birth weight was also reported by Nahid. ${ }^{11}$ Also, an increase in the cesarean section was noted with increasing gestational age which was also highly significant $\left(\chi^{2}=60.54, \mathrm{df}=3, p=0.000\right)$.

It was observed that $65.38 \%$ of vaginally delivered babies had Apgar score more than 7 at 5 min of birth as compared to $87.61 \%$ of babies delivered by emergency cesarean section and $100 \%$ of babies delivered by elective cesarean section. Low Apgar scores were noted for the vaginally delivered babies as compared to those delivered by cesarean section and the difference was highly significant $\left(\chi^{2}=21.676, \mathrm{df}=2, p=0.000\right)$. Overall 85.32\% of babies had Apgar score more than 7 at 5 minutes of birth. Such a trend was also observed by Nahid. ${ }^{11}$

Low Apgar scores were noted for the vaginally delivered babies as compared to those delivered by cesarean section, and the difference was highly significant $\left(\chi^{2}=\right.$ $21.676, \mathrm{df}=2, p=0.000$ ). This difference can be explained due to an increased number of preterm births in the vaginal delivery group and because cesarean sections were planned at a comparatively advanced gestation. Apgar scores distribution as per the gestational age over the different groups seems comparable as can be seen from Table 4. Follow-up of the babies 6 weeks later did not reveal any difference in the outcome among the different groups. Studies have shown that poor outcome of very low birth weight babies is related to prematurity and its complications mainly rather than the mode of delivery. ${ }^{14}$ Uotila J found lower Apgar scores in the group of planned vaginal breech delivery, but in other outcome measures, 
there were no significant intergroup differences. ${ }^{15}$ An Austrian study has shown comparable fetal outcomes in vaginal delivery and planned cesarean section in the presence of standby service system of a senior obstetrician. ${ }^{16}$ No significant differences were noted in neonatal outcomes in the study by Sanchez-Ramos et al. ${ }^{17}$ Also, it has been shown that immediate admission to NICU has no long term effects. ${ }^{18}$ Thus, carefully selected patients may undergo a planned vaginal breech delivery after proper counseling and informed choice of the patient.

\section{CONCLUSION}

The present study concludes that planned vaginal delivery of both preterm and term breech in a carefully selected patient can be conducted after proper counseling of the patient with strict intrapartum monitoring and presence of obstetricians trained in the art of conducting breech deliveries. Delivery of breech vaginally and regular drills give an opportunity to train residents in this art and thus more skilled obstetricians are ready to tackle unavoidable vaginal deliveries as in advanced labor. Although planned cesarean section seems better, it increases maternal morbidity and complications associated with cesarean section. In countries with poor resources and high rates of perinatal mortality, planned vaginal delivery of selected patients will yield comparable outcomes.

\section{REFERENCES}

1. Hickok DE, Gordon DC, et al. The frequency of breech presentation by gestational age at birth: a large population-based study. Am J Obstetr Gynecol 1992;166(3):851-852.

2. Gilbert WM, Hicks SM, et al. Vaginal versus cesarean delivery for breech presentation in california: a population based study. Obstetr Gynecol 2003;102(5, Part 1):911-917.

3. Abasiattai AM, Etuk SJ, et al. Perinatal outcome following singleton vaginal breech delivery in the University of Calabar Teaching Hospital, Calabar: a 10-year review. Mary Slessor J Med 2005; 4(1):81-85.

4. Luterkort M, Persson PH, et al. Maternal and fetal factors in breech presentation. Obstetr Gynecol 1984;64(1):55-59.
5. Hannah ME, Hannah WJ, et al. Planned caesarean section versus planned vaginal birth for breech presentation at term: a randomised multicentre trial. The Lancet 2000;356(9239):13751383.

6. Ghosh MK. Breech presentation: evolution of management. J Reproduct Med 2005;50(2):108-116.

7. Glezerman M. Five years to the term breech trial: the rise and fall of a randomized controlled trial. Am J Obstetr Gynecol 2006;194(1):20-25.

8. Whyte H, Hannah ME, et al. Outcomes of children at 2 years after planned cesarean birth versus planned vaginal birth for breech presentation at term: the International Randomized Term Breech Trial. Am J Obstetr Gynecol 2004;191(3): 864-871.

9. Goffinet F, Carayol M, et al. Is planned vaginal delivery for breech presentation at term still an option? Results of an observational prospective survey in France and Belgium. Am J Obstetr Gynecol 2006;194(4):1002-1011.

10. Singh A, Mishra N, et al. Delivery in breech presentation: the decision making. The Journal of Obstetrics and Gynecology of India. 2012 Aug 1;62(4):401-405.

11. Nahid F. Outcome of singleton term breech cases in the pretext of mode of delivery. J Pakistan Med Assoc 2000;50(3):81-85.

12. Nkwabong E, Fomulu JN, et al. Outcome of breech deliveries in Cameroonian nulliparous women. J Obstetr Gynecol India 2012;62(5):531-535.

13. Bassaw B, Rampersad N, et al. Correlation of fetal outcome with mode of delivery for breech presentation. J Obstetr Gynaecol 2004;24(3):254-258.

14. Cibils LA, Karrison T, et al. Factors influencing neonatal outcomes in the very-low-birth-weight fetus ( $<1500$ grams) with a breech presentation. Am J Obstetr Gynecol 1994;171(1): 35-42.

15. Uotila J, Tuimala R, et al. Good perinatal outcome in selective vaginal breech delivery at term. Acta Obstetricia et Gynecologica Scandinavica 2005;84(6):578-583.

16. Maier B, Georgoulopoulos A, et al. Fetal outcome for infants in breech by method of delivery: experiences with a stand-by service system of senior obstetricians and women's choices of mode of delivery. J Perinat Med 2011;39:385-390.

17. Sanchez-Ramos L, Wells TL, et al. Route of breech delivery and maternal and neonatal outcomes. Int J Gynecol Obstetr 2001;73(1):7-14.

18. Vistad I, Cvancarova M, et al. Vaginal breech delivery: results of a prospective registration study. BMC Pregnancy and Childbirth 2013;13(1):1. 